\title{
Hydrogen metabolism in aerobic hydrogen-oxidizing bacteria.
}

Bernhard SCHINK and Hans-Günter SCHLEGEL.
Institut für Mikrobiologie der Gesellschaft

für Strahlen- und Umweltforschung

mbH München, und der Universität Göttingen, 3400 Göttingen, Grisebachstr. 8,

Federal Republic of Germany.

\section{Summary.}

A survey on organisms able to use molecular hydrogen as electron donor in the energyyielding process is presented. In the group of the aerobic hydrogen-oxidizing bacteria so far two types of hydrogenases have been encountered, a NAD-reducing, soluble enzyme $\left(\mathrm{H}_{2}\right.$ : NAD oxidoreductase) and a membranebound enzyme unable to reduce pyridine nucleotides. With respect to the distribution of both types of hydrogenases three groups of hydrogen-oxidizing bacteria can be diffentiated containing (i) both types (Alcaligenes eutrophus), (ii) a soluble enzyme only (Nocardia opaca lb), and (iii) a membrane-bound hydrogenase only (majority of genera and species). The results of studies on the NADspecific hydrogenase of $A$. eutrophus are summarized. Results on the solubilization and purification of the membrane-bound hydrogenase of $A$. eutrophus are presented in detail. The enzyme was solubilized from purified membranes by Triton X-100 and sodium desoxycholate or phospholipase $D$. The crude membrane extract was fractionated by ammonium sulfate precipitation and chromatography on carboxymethylcellulose at $\mathrm{pH}$ 5.5. The enzyme was stable in potassium phosphate buffer: it resembles the soluble enzyme with respect to stability under oxidizing conditions. Further biochemical and immunological data indicate, however, that both enzymes are different with respect to their native structure.

use hydrogen for aerobic respiration and the reduction of carbon dioxide. The second group, which is able to utilize hydrogen under anaerobic conditions only, comprises various metabolic types, chemotrophic as well as phototrophic bacteria. The chemotrophic hydrogen-utilizing bacteria are the methanogenic bacteria (e.g., Metha- nosarcina barkeri), the acetogenic bacteria (e.g.,
Several metabolic types of organisms are able to use molecular hydrogen (dihydrogen or $\mathrm{H}_{2}$ ) as an electron donor in the energy-yielding process. Two groups have to be considered. The first group comprises bacteria utilizing hydrogen under aerobic conditions. These are the chemolithoautotrophic, aerobic hydrogen-oxidizing bacteria (e.g. Alcaligenes eutrophus); they are able to 
Ciostridium aceticum and Acetobacterium woodii), the sulfate-reducing bacteria (e.g., Desulfovibrio vulgaris), the nitrate-reducing, denitrifying bacteria (e.g. Paracoccus denitrificans) and the fumarate-reducing bacteria (e.g., Escherichia coli). Among the phototrophic bacteria there are at least some species able to grow with hydrogen as an electron donor in each of the major families, Chromatiaceae (e.g., Chromatium vinosum, Thiocapsa roseopersicina), Rhodospirillaceae (e.g., Rhodospirillum rubrum, Rhodopseudomonas capsulata) and Chlorobiaceae (e.g., Chlorobium limicola var. thiosulphatophilum). Some cyanobacteria and a few green algae can be adapted to use hydrogen for anoxygenic photosynthesis. The carbon source used together with hydrogen is carbon dioxide, at least in the majority of the bacteria using $\mathrm{H}_{2}$ as source of reducing power and energy; only the sulfate- and the fumaratereducing bacteria lack the ability to fix $\mathrm{CO}_{2}$ autotrophically.

There are many bacteria that are able to activate hydrogen in addition to those mentioned. They share the presence of hydrogenases, as the enzymes activating or/and releasing hydrogen gas are collectively called. For example, all nitrogenfixing bacteria, the rhizobia included, possess hydrogenases ; it is assumed that in these bacteria hydrogenase recycles the hydrogen evolved by nitrogenase thus preventing waste of energy and protecting the nitrogenase from inactivation by oxygen $[1]$. The obvious questions related to hydrogen utilization for energy generation by non-autotrophic bacteria have not been definitely resolved.

This report will deal with the first group only, the aerobic chemoautotrophic bacteria, hereafter plainly called the hydrogen-oxidizing bacteria. These bacteria comprise a physiological group; they are facultatively autotrophic bacteria and share the ability to grow with hydrogen as electron donor and with carbon dioxide as the sole carbon source.

The stoichiometry of the consumption of the gaseous substrates by these bacteria is dependent on the growth conditions and growth rate and varies from strain to strain. Hydrogen is used in the oxygen-hydrogen reaction serving the generation of energy (equation 1) and in the fixation of $\mathrm{CO}_{2}$ to the level of cellular material (equation 2). The ratio of hydrogen uptake over the uptake of carbon dioxide $\left(\mathrm{H}_{2} / \mathrm{CO}_{2}\right)$ by a suspension of growing cells is dependent on the efficiency of coupling, on the expenditure for maintenance energy and on the level, at which the electrons enter the respiratory chain $\mathrm{H}_{2} / \mathrm{CO}_{2}$ ratios of 4 to 10 have been measured. The average ratio measured with Alcaligenes entrophus is represented in equation 3 .

$2 \mathrm{H}_{2}+\mathrm{O}_{2} \longrightarrow 2 \mathrm{H}_{2} \mathrm{O}$

$2 \mathrm{H}_{2}+\mathrm{CO}_{2} \longrightarrow<\mathrm{CH}_{2} \mathrm{O}>+\mathrm{H}_{2} \mathrm{O}$

$6 \mathrm{H}_{2}+2 \mathrm{O}_{2}+\mathrm{CO}_{2} \longrightarrow<\mathrm{CH}_{2} \mathrm{O}>+5 \mathrm{H}_{2} \mathrm{O}$

Carbon dioxide fixation occurs via the ribulosebisphosphate cycle. So far, among the aerobic autotrophs no member has been found which assimilates $\mathrm{CO}_{2}$ via another pathway. Thus, the spectacular ability of the aerobic hydrogen-oxidizing bacteria to grow with $\mathrm{H}_{2}+\mathrm{CO}_{2}$ as the sole energy and carbon substrates is due to the combination of $\mathrm{CO}_{2}$ fixation and hydrogen oxidation, with ribulosebisphosphate carboxylase, phosphoribulokinase and hydrogenase(s) as the main key enzymes. Otherwise, the hydrogen bacteria are not different from normal heterotrophic bacteria; they are able to grow on organic substrates as well.

Taxonomically the aerobic hydrogen-oxidizing bacteria are a heterogeneous group containing Gram-negative genera, such as Alcaligenes, Pseudomonas, Paracoccus, Aquaspirilium, Flavobacterium, Corynebacterium as well as Gram-positive genera such as Nocardia, Mycobacterium and Bacillus ([2]; Aragno and Schlegel, in preparation).

\section{Hydrogenases, their distribution and regulation.}

Hydrogenase is the collective name of a multitude of enzymes either activating or releasing hydrogen. In most cases neither the physiological electron acceptor nor the properties of the enzymes are known [3]. Some hydrogenases reduce NAD, others ferredoxin, menaquinone or cytochrome $\mathrm{c}$; the ability to reduce some redox dyes is common to all hydrogenases.

So far two types of hydrogenase have been encountered in the aerobic hydrogen-oxidizing bacteria. The one is a NAD-reducing, soluble enzyme $\left(\mathrm{H}_{2}\right.$ : NAD oxidoreductase) and the other is a membrane-bound enzyme unable to reduce pyridine nucleotides. With respect to the distribution of both types of hydrogenases three groups of hydrogen-oxidizing bacteria can be differentiated (table I) :

(i) Alcaligenes eutrophus [4], A. ruhlandii, [5] and Pseudomonas saccharophila [6] contain both types, the soluble and the membrane-bound hydrogenase ; (ii) Nocardia opaca lb (7) and some further species of the genus Nocardia contain a soluble, NAD-reducing enzyme only; (iii) the majority of the hydrogen-oxidizing bacteria, such 
as Alcaligenes latus, Aquaspirillum autotrophicum, Paracoccus denitrificans, several pseudomonads and the coryneform nitrogen-fixing strains, contain only a membrane-bound hydrogenase [8].
(Entner-Doudoroff) enzymes is repressed [11]. In contrast, in Paracoccus denitrificans glucose is the dominant substrate, and hydrogenase formation is repressed [12]. The latter type of regu-

TABLE I.

Hydrogen-oxidizing bacteria and the localization of hydrogenases.

\begin{tabular}{|c|c|c|c|c|}
\hline \multirow{2}{*}{ Species } & \multicolumn{4}{|c|}{ Hydrogenase } \\
\hline & soluble & $\begin{array}{c}\text { membrane- } \\
\text { bound }\end{array}$ & $\begin{array}{l}\text { nitrogen } \\
\text { fixation }\end{array}$ & $\begin{array}{c}\text { Gram } \\
\text { stain }\end{array}$ \\
\hline Alcaligenes eutrophus & + & + & - & - \\
\hline Alcaligenes paradoxus & $\underline{I}$ & I & - & - \\
\hline Alcaligenes ruhlandii & + & + & - & - \\
\hline Alcaligenes latus & & & - & - \\
\hline Pseudomonas facilis & - & I & - & - \\
\hline Pseudomonas saccharophila & + & + & - & - \\
\hline Pseudomonas carboxydovorans & & & -. & - \\
\hline Pseudomonas pseudoflava & - & + & - & - \\
\hline Pseudomonas palleronii & - & t & - & - \\
\hline $\begin{array}{l}\text { Pseudomonas hydrogenovora } \\
\text { Pseudomonas hydrogenothermophila }\end{array}$ & - & + & - & 二 \\
\hline Flavobacterium autothermophilum & - & + & - & - \\
\hline Hydrogenomonas thermophilus & & & & - \\
\hline Aquaspirillum autotrophicum & - & + & - & - \\
\hline Paracoccus denitrificans & - & & - & - \\
\hline «Corynebacterium» autotrophicum & - & + & + & - \\
\hline Nocardia opaca $1 \mathrm{~b}$ & + & - & - & + \\
\hline Nocardia autotrophica & + & - & - & \\
\hline Mycobacterium gordonae & $\frac{1}{-}$ & + & - & - \\
\hline Arthrobacter sp. (11X, RH 12) & - & + & - & + \\
\hline Seliberia carboxydohydrogena & & & - & - \\
\hline
\end{tabular}

The regulation of hydrogenase formation in these bacteria is not well known [9]. All aerobic hydrogen bacteria are facultatively autotrophic bacteria and are able to grow under autotrophic conditions with $\mathrm{CO}_{2}+\mathrm{H}_{2}$ as well as under heterotrophic conditions on a number of organic compounds as substrates, such as sugars, organic acids, and amino acids. Maximum hydrogenase activity is found in autotrophically grown cells. In heterotrophically grown cells hydrogenase is either absent or present in minor specific activities; in Alcaligenes eutrophus the specific total hydrogenase activity depends on the kind of organic substrate (table II) and the growth rate $[10]$. When the cells are exposed to both energy donors, hydrogen and an organic substrate, the response is different in different strains; a kind of catabolite repression may be operative. In Alcaligenes eutrophus hydrogen is the dominant substrate; in the presence of hydrogen and fructose the formation of the fructose degrading lation seems to predominate among the hydrogen bacteria. In addition, hydrogen can exert an inhibitory effect on the utilization of the organic substrate. In Alcaligenes eutrophus $\mathrm{Hl6}$ hydrogen inhibits the utilization of fructose; this effect turned out to be due to the inhibition of glucose-6phosphate dehydrogenase $[13]$; in $A$. eutrophus this enzyme is sensitive to ATP and $\mathrm{NADH}_{2}$. From following the pool sizes of glucose-6-phosphate, 6-phosphogluconate, ATP and $\mathrm{NADH}_{2}$ during transition of the cells from air to a hydrogenoxygen mixture it was concluded that glucose-6phosphate dehydrogenase is the regulatory enzyme and that in vivo the inhibition is caused by the increase in the $\mathrm{NADH}_{2}$ concentration [14].

The presence of two hydrogenases has been described for Pseudomonas saccharophila [6], Alcaligenes ruhlandii $[15 ; 5]$ and Alcaligenes eutrophus [4]. The soluble enzyme has been recently purified and characterized. The results 
have been published $[16 ; 8]$ and will only be summarized here.

The soluble hydrogenase of Alcaligenes eutrophus.

Eleven strains of Alcaligenes eutrophus were used to examine the stability of the soluble hydrogenase, and strain $\mathrm{HI} 6$ was selected as the enzyme of a flavin component. It was identified as being FMN by thin layer chromatography, fluorescence spectrum and fluorescence quenching by the addition of apoflavodoxin.

The molecular weight is 205000 . The isoelectric point was found to be 4.85 . The $\mathrm{pH}$ optimum was 8.0, the optimal temperature $33^{\circ} \mathrm{C}$, and the $\mathrm{Mi}$ -

TABLE II.

Rate of hydrogen oxidation by intact cells of Alcaligenes eutrophus $H 16$ after growth on glutamate, lactate or fructose compared to autotrophically grown cells.

\begin{tabular}{|c|c|c|c|}
\hline \multirow{2}{*}{$\begin{array}{l}\text { Multiplication } \\
\text { factor of cell protein } \\
\text { during growth } \\
\text { on organic substrate }\end{array}$} & \multicolumn{3}{|c|}{$\begin{array}{c}\text { Rate of hydrogen oxidation }\left(\mu \mathrm{mol} \mathrm{H}_{2} / \mathrm{min} . \mathrm{m} \text { p protein) }\right. \\
\text { after growth on }\end{array}$} \\
\hline & $\begin{array}{c}\text { Glutamate } \\
85 \text { per cent } \mathrm{N}_{2} \\
+5 \text { per cent } \mathrm{O}_{2} \\
+10 \text { per cent } \mathrm{CO}_{2}\end{array}$ & $\begin{array}{c}\text { Lactate } \\
85 \text { per cent } N_{2} \\
+5 \text { per cent } \mathrm{O}_{2} \\
+5 \text { per cent } \mathrm{CO}_{2}\end{array}$ & $\begin{array}{c}\text { Fructose } \\
\text { Air }\end{array}$ \\
\hline Autotrophic culture & 1.36 & 1.45 & 1.26 \\
\hline ca. $10^{2}$ & 0.454 & 0.056 & 0.651 \\
\hline ca. $10^{4}$ & - & - & 0.484 \\
\hline ca. $10^{6}$ & 0.160 & 0.056 & - \\
\hline $10^{8}$ & - & 0 & 0.424 \\
\hline
\end{tabular}

Rates of total gas uptake were measured in an atmosphere of 85 per cent $\mathrm{H}_{2}+5$ per cent $\mathrm{O}_{2}+10$ per cent $\mathrm{CO}_{2}(10)$.

The rate of hydrogen oxidation was calculated assuming ratio.

$\mathrm{H}_{2}: \mathrm{O}_{2}: \mathrm{CO}_{2}=6: 2: 1$.

source. The enzyme was purified 68 -fold with a yield of 20 percent and a specific activity (NADreduction) of $54 \mu \mathrm{mol} \mathrm{H}_{2}$ oxidized per min and $\mathrm{mg}$ protein. The enzyme is not only insensitive to oxygen, its stability can even be increased by oxygen treatment or the addition of oxidizing agents like ferricyanide $(0.5 \mathrm{mM})$. The enzyme, which was homogeneous by the criterium of polyacrylamide gel electrophoresis, is not strictly NAD-specific. In its reactive state it has the ability to react in the absence of NAD $(\mathrm{H})$ with a large number of artificial and physiological hydrogen acceptors such as methylene blue, ferricyanide, dichlorophenol indophenol, phenazinemethosulfate, viologen dyes, FMN, FAD, ubiquinone, cytochrome $\mathrm{c}$ and oxygen. In some cases the reduction rates were even up to 5-fold higher than with NAD. The enzyme catalyzed the evolution of hydrogen from NADH, dithionite-reduced methylviologen and benzylviologen. It exhibited diaphorase and NAD (P) $\mathrm{H}$ oxidase activity.

In accordance with the low acceptor specificity and with diaphorase activity was the presence chaelis constants for NAD and $H_{2}$ were 0.56 and $0.037 \mathrm{mM}$, respectively.

The membrane-bound hydrogenase of A. eutrophus.

The existence of two enzymes for the activation of hydrogen in A. eutrophus, a soluble and a membrane-bound one, raised the question, whether these two hydrogenases were two independent isozymes or one enzyme protein exhibiting different properties due to its localization in different sites in the cell. Preliminary experiments indicated almost coordinate formation of both enzymes [17]. However, these observations contradicted the differences in their biochemical behaviour. For further differentiation of both hydrogenase activities, the membrane-bound hydrogenase had to be purified and compared to the soluble enzyme. Since the results have not yet been published, the solubilization, purification, and some properties of the membrane-bound hydrogenase will be described in some detail. 
TABLE III.

Solubilization of the membrane-bound hydrogenase of A. eutrophus by different agents (usually in KP buffer $50 \mathrm{mM}, \mathrm{pH} 7.0$ ).

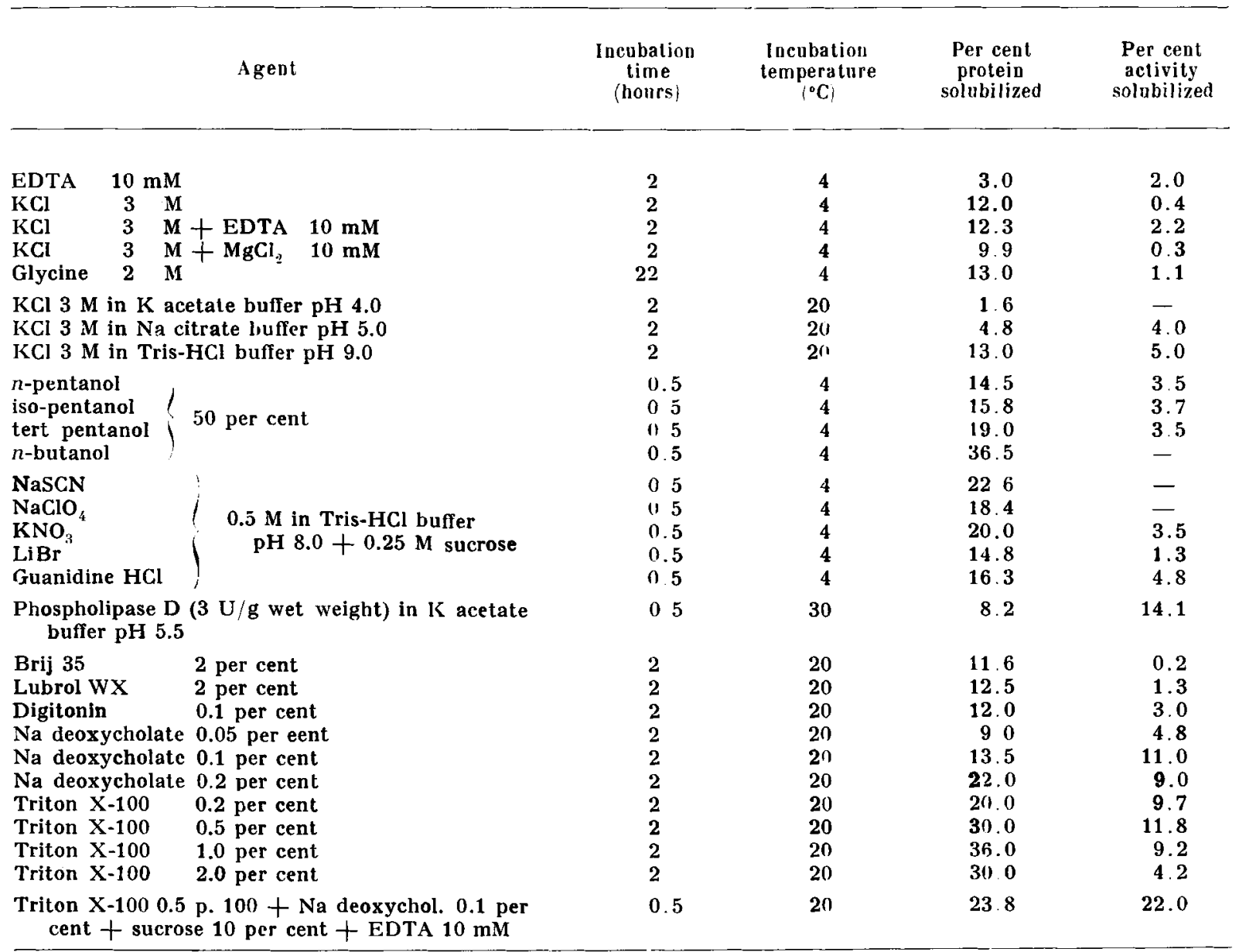

When the investigation on the membrane-bound hydrogenase was started only a few data were known; these concerned the hydrogen oxidase system in intact membranes. The activity of hydrogen oxidase was stable in frozen membrane preparations under air, and it was inhibited by oxygen at concentrations over $70 \mu \mathrm{M}[18,19]$. Quinones and cytochromes of the b, c, a, $a_{3}$, and o type were involved in the electron transfer system from hydrogen to oxygen $[20]$. In situ the hydrogenase reacted only with artificial electron acceptors like methylene blue, phenazinemethosulfate, and dichlorophenolindophenol ; it did not react with pyridine nucleotides. The physiological electron acceptors were unknown. Hydrogenase activity of membrane preparations was usually determined manometrically under hydrogen atmosphere with methylene biue as electron acceptor.

For rapid determination of hydrogenase activity in membranes and in solubilized preparations the following test system was used. A solution of $200 \mu \mathrm{M}$ methylene blue in $50 \mathrm{mM}$ potassium phosphate buffer, $\mathrm{pH}$ 7.0, was kept under hydrogen gas and pipetted into $3 \mathrm{ml}$ cuvettes. These were flushed with hydrogen before and after adding the buffer. Glucose (0.2 umol), glucose oxidase (1 unit) and catalase ( 1 unit) were added as an oxygen trap. The reaction was started by adding the membrane suspension or solution containing the hydrogenase, and the absorption decrease was followed photometrically at $570 \mathrm{~nm}$ wave-length. 
The results were in accordance with those derived from manometric tests.

The cytoplasmic membranes were prepared by sonication, treatment by lysozyme followed by osmotic shock, and in the French pressure cell. In these preparations the hydrogenase activity was stable when frozen under air. Due to their relatively high specific hydrogenase activities, sonicated membranes were used for solubilization. The membranes were washed with phosphate buffer and resuspended in the same buffer to a protein content of about $3-4 \mathrm{mg} / \mathrm{ml}$. After adding the solubilizing agent, the membrane suspension was stirred for 0.5 to $22 \mathrm{~h}$. The insoluble debris was removed by centrifugation at $100000 \mathrm{~g}$. Hydrogenase activity and protein content were determined in the supernatant. The results of various attempts to solubilize the enzyme are summarized in table III.

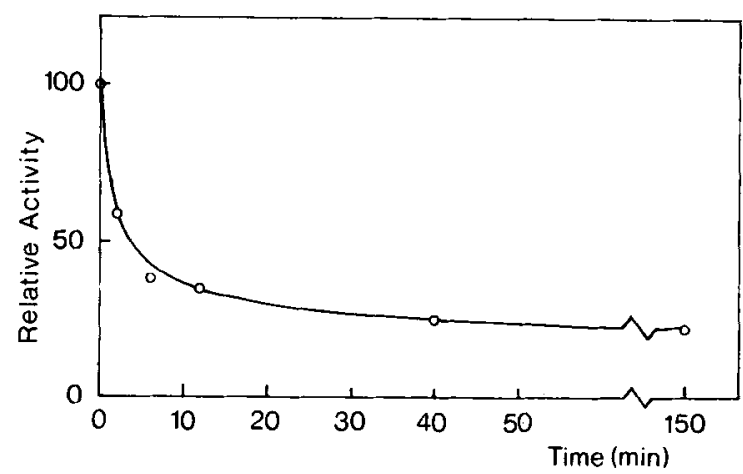

FIG. 1. - Kinetics of the solubilization of the membrane-bound hydrogenase of A. eutrophus $H 16$ by the combination of Triton $\mathrm{X}-100$ and Na-deoxycholate.

Protein content : $2.4 \mathrm{mg} / \mathrm{ml}$. The decrease of hydrogenase activity is the result of the shift of the $\mathrm{pH}$ optimum during solubilization.

Only low hydrogenase activities were released by the incubation of the membranes in the presence of potassium chloride, magnesium chloride or EDTA, in acidic or alkaline buffers. Alcohols as well as chaotropic agents decreased the hydrogenase activity. Satisfactory results were obtained with Triton $\mathrm{X}-100$ and sodium deoxycholate as well as with phospholipase $D$. These results indicated the hydrogenase enzyme being tightly bound to the nembrane. The enzyme protein is apparently in close contact to the lipid membrane layer and has to be regarded as an integral, not a peripheral membrane protein.
The following procedure for solubilizing hydrogenase in a preparative scale has been finally used (after Yu and Wolin, [21] ; modified) : membranes prepared by sonication were washed with potassium phosphate buffer and again with this buffer supplemented by $0.15 \mathrm{M} \mathrm{NaCl}$ and $0.25 \mathrm{M}$ sucrose for removing proteins loosely bound to the membrane surface. The membranes were resuspended in phosphate buffer to a protein content of 4 to $5 \mathrm{mg} / \mathrm{ml}$. 10 per cent sucrose, $10 \mathrm{mM}$ EDTA, 0.1 per cent deoxycholate, and 0.5 per cent Triton $X-100$ (final concentrations) were added, and after stirring for $30 \mathrm{~min}$ at room temperature, membrane particles not solubilized were removed by centrifugation. A maximal yield of 22 per cent of the hydrogenase activity of intact membranes was solubilized. As explained later, this corresponds to almost the total amount of hydrogenase present in the membranes. The apparent loss of activity turned out to be due to a change in the $\mathrm{pH}$ optimum of the hydrogenase after solubilization. The pH optimum change made it possible to follow the solubilization process by measuring the decrease of enzyme activity in the membrane sus-

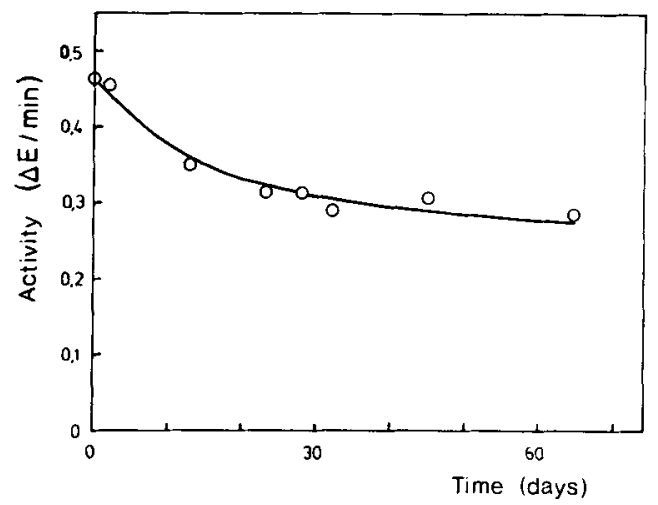

FIg. 2. - Decrease of activity of the solubilized membrane-bound hydrogenase during storage at $-18^{\circ} \mathrm{C}$ under air.

pension after the addition of detergents (fig. 1). Already after 20 min more than 90 per cent of the hydrogenase was solubilized. The velocity of this process was not influenced by the incubation temperature between 4 and $30^{\circ} \mathrm{C}$.

The yellow supernatant tolerated storage under air at $-18^{\circ} \mathrm{C}$ for two months almost without loss of enzyme activity (fig. 2). During storage at $4^{\circ} \mathrm{C}$ under air for two days the loss was 10 per cent, whereas under reducing conditions (addition of 
mercaptoethanol or hydrogen) the loss was 70 per cent. The membrane-bound hydrogenase turned out to be stable under oxidizing and unstable under reducing conditions ; in this respect it resembles the soluble hydrogen dehydrogenase.

The yellow supernatant, which contained proteins, lipids, detergents, sucrose, and EDTA, was fractionated by ammonium sulfate precipitation. In the first step ammonium sulfate was added to give a 25 per cent saturated solution. After centrifugation the emulsion was separated into an oily, red coloured supernatant layer and a clear aqueous solution containing the hydrogenase. The supernatant layer could be fixed to the surface by adding light petroleum or hexane before centrifu- phate buffer. After dialysis and centrifugation, the supernatant was chromatographed on CM-celIulose (Whatman CM 52) equilibrated with $25 \mathrm{mM}$ potassium acetate buffer, $\mathrm{pH} 5.5$, in a $1.5 \times 30 \mathrm{~cm}$ column using a $200 \mathrm{ml}$ linear gradient from 0 to $0 . \overline{\mathrm{M}} \mathrm{KCl}$. Fractions with a volume of $2 \mathrm{ml}$ were collected. Profiles of hydrogenase and protein content are presented in figure 3 .

A high amount of protein with low hydrogenase activity passed the column. The hydrogenase was eluted in two adjacent peaks. The fractions of both activity peaks were concentrated separately by ultrafiltration to a protein content of $1.0 \mathrm{mg} / \mathrm{ml}$ and dialyzed against potassium phosphate buffer, pH 7.0 .

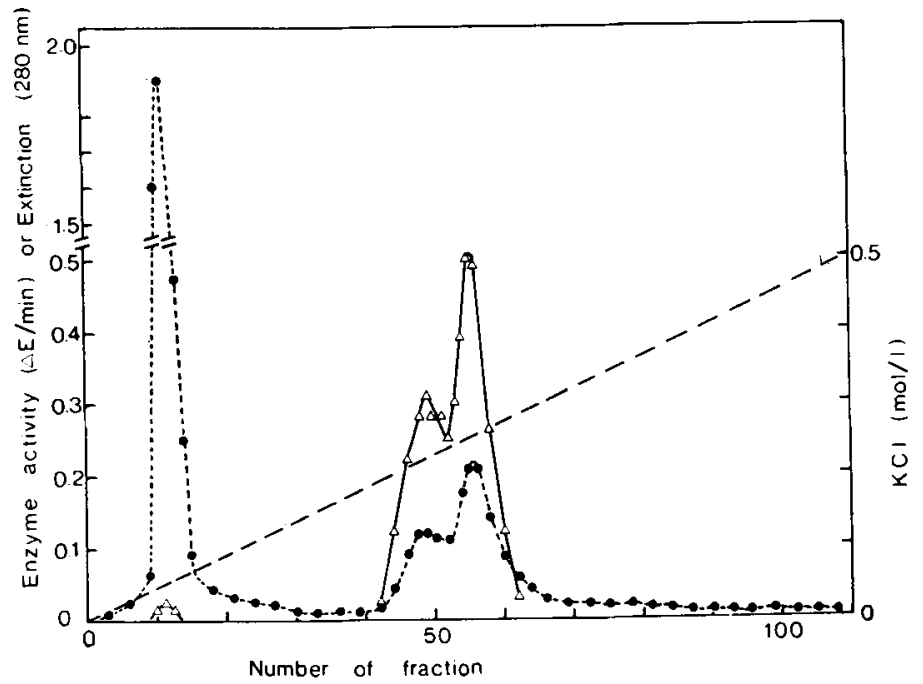

Fig. 3. - Elution profile of the membrane-bound hydrogenase during chromatography on CM-cellulose.

$9 \mathrm{mg}$ of protein were applied to the column equilibrated with potassium acetate buffer $25 \mathrm{mM} \mathrm{pH} 5.5$ and eluted by a linear gradient of 0 to $0.5 \mathrm{M} \mathrm{KCl}$. Fractions of $2 \mathrm{ml}$ were collected.

Symbols : - protein content, measured as extinction at $280 \mathrm{~nm} ; \Delta-\Delta$ hydrogenase activity, measured as the rate of methylene blue reduction.

gation; the aqueous solution was easily sucked off with a pipette. This procedure was repeated after increasing the ammonium sulfate concentrations to 30 per cent saturation. The hydrogenase remained in the aqueous solution. Hydrogenase was precipitated by ammonium sulfate between 40 and 55 per cent saturation. The precipitate was dissolved in phosphate buffer and again precipitated by ammonium sulfate between 45-60 per cent saturation. The precipitate was dissolved in phos-
The total purification procedure is summarized in table IV. For comprehension of the low values of activity recovered after enzyme solubilization it has to be mentioned that activity was consistently measured at $\mathrm{pH} 7.0$, which is about the optimum $\mathrm{pH}$ for the hydrogenase bound to the membrane. The solubilized enzyme has a $\mathrm{pH}$ optimum at $\mathrm{pH}$ 5.5. At $\mathrm{pH} 7.0$, the solubilized enzyme has only 24 per cent of the activity measured at pH 5.j. For making out a balance-sheet of the 
TABLE IV.

Solubilization and purification of the membrane-bound hydrogenase

of $\mathrm{A}$. eutrophus.

\begin{tabular}{|c|c|c|c|c|c|}
\hline Step & $\begin{array}{l}\text { Total } \\
\text { protein } \\
\text { (mg) }\end{array}$ & $\begin{array}{c}\text { Total } \\
\text { activity } \\
\text { (units) }\end{array}$ & $\begin{array}{l}\text { Specific } \\
\text { activity } \\
\text { (nnits/g } \\
\text { protein) }\end{array}$ & $\begin{array}{l}\text { Purifi- } \\
\text { cation } \\
(- \text { fold })\end{array}$ & $\begin{array}{l}\text { Yield } \\
(\text { per cent) }\end{array}$ \\
\hline Washed membranes & 1890 & 1870 & 990 & 1.0 & 100 \\
\hline Washing by $\mathrm{NaCl} /$ sucrose & 1620 & 1810 & 1120 & 1.13 & 96 \\
\hline Solubilization & 360 & $\left.\begin{array}{ll} & 430 \\
(1 & 770\end{array}\right)$ & $\begin{array}{rl}1 & 200 \\
(4 & 950)\end{array}$ & $\begin{array}{l}1.21 \\
(5.0)\end{array}$ & $\begin{array}{c}23 \\
(95)\end{array}$ \\
\hline $\begin{array}{l}\text { 1. Precipitation with ammonium } \\
\text { sulfate (40-55 per cent) }\end{array}$ & 37 & $\begin{array}{ll} & 286 \\
1 & 180\end{array}$ & $\begin{array}{rr}7 & 700 \\
(31 & 700)\end{array}$ & $\begin{array}{c}7.8 \\
(32.0)\end{array}$ & $\begin{array}{l}15.3 \\
(63\end{array}$ \\
\hline $\begin{array}{l}\text { 2. Precipitation with ammonium } \\
\text { sulfate (45-60 per cent) }\end{array}$ & 9 & $\begin{array}{c}240 \\
(990)\end{array}$ & $\begin{array}{rl}26 & 700 \\
(110 & 000)\end{array}$ & $\begin{array}{c}27.0 \\
(111.0)\end{array}$ & $\begin{array}{c}12.8 \\
(55.0)\end{array}$ \\
\hline CM-cellulose chromatography & 4.2 & $\begin{array}{c}165 \\
(685)\end{array}$ & $\begin{array}{rl}41 & 300 \\
(170 & 000)\end{array}$ & $\begin{array}{l}41.7 \\
(172)\end{array}$ & $\begin{array}{c}8.8 \\
(35.8)\end{array}$ \\
\hline
\end{tabular}

whole purification procedure, the activities have to be multiplied by the factor 4.1 (values in brackets). Comparing the values obtained after the first washing of the membranes with those of the two purified enzyme fractions obtained after CM-cellulose chromatography, one calculates a yield of 35.8 per cent, an enrichment factor of 172 and a specific activity of $170 \mu \mathrm{mol} \mathrm{H}_{2}$ oxidized per min and $\mathrm{mg}$ protein.

Both fractions of purified enzyme separated by carboxymethyl cellulose chromatography were homogeneous by means of polyacrylamide gel electrophoresis at different polyacrylamide concentrations, only their $\mathrm{R}_{\mathrm{f}}$-values differed slightly. However, these were the only differences between the two fractions we found. A mixture of both turned out to be homogeneous in isoelectric focusing, in gel filtration on Sephadex G 200, and in sucrose gradient centrifugation. Sodium dodecylsulfate gel electrophoresis revealed no differences in subunit composition. The «greater» or «less polar» molecule, however, was not stable, but gradually changed to the other one during storage for several days. In fresh crude solubilized preparations almost only the "greater» molecule was found as demonstrated by activity staining the hydrogenase in polyacrylamide gel slabs by phenazinemethosulfate and nitroblue tetrazolium, chloride under hydrogen (method according to 16). On the basis of these data it may be assumed that both types of hydrogenase molecules differ from each other by the amount of adherent phospholipid or detergent attached to unpolar regions of the enzyme.

\section{Concluding remarks.}

The majority of species of the hydrogen bacteria have a membrane-bound hydrogenase only [8]. The possession of a single enzyme is shared with Azotobacter vinelandii [22], Rhizobium bacteroids [1] and many facultatively and strictly anaerobic bacteria as well as phototrophic bacteria $[23,24]$. The study of these enzymes lends itself as an approach to reveal relationships among the hydrogen-oxidizing bacteria as well as between this group, the phototrophic and the nonautotrophic hydrogenase containing bacteria.

The progress in the studies on the hydrogenases of Alcaligenes eutrophus so far revealed similarities and differences. Both the NiAD-reducing, soluble and the membrane-bound hydrogenase are remarkably stable to oxygen, they are inactivated when stored under reducing conditions. However, the enzymes are different in several basic properties ; these differences concern the electron acceptor specificities, the isoelectric points, the molecular weights and the $\mathrm{pH}$ and temperature optina. Immunodiffusion experiments done with antisera prepared against both purified enzymes did not show any cross reactions between both enzyme proteins. The native enzymes are different proteins.

\section{REFERENCES.}

1. Dixon, R. O. D. (1972) Arch. Mikrobiol., 85, 193-201.

2. Schlegel, H. G. (1975) in "Marine Ecology» (Kinne, O. ed.), vol. II, part I, pp. 9-60, John Wiley \& Sons, London. 
3. Mortenson, L. E. \& Chen, J.-S. (1974) in «Microbial Iron Metabolism»(Neilands, J. B. ed.), pp. 231282, Academic Press, New York and London.

4. Eberhardt, U. (1966) Arch. Mikrobiol., 53, 288-302.

5. Bone, D. H., Bernstein, S. \& Vishniac, W. (1963) Biochim. Biophys. Acta, 67, 581-588.

6. Bone, D. H. (1960) Biochem. Biophys. Res. Commun, 3, 211-214.

7. Aggag, M. \& Schlegel, H. G. (1974) Arch. Microbiol., 100, 25-39.

8. Schneider, K. \& Schlegel, H. G. (1977) Arch. Microbiol., 112, 229-238.

9. Schlegel, H. G. \& Eberhardt, U. (1972) Adv. Microb. Physiol., 7, 205-242.

10. Eberhardt, U. (1966) Arch. Mikrobiol, 54, 115-124.

11. Gottschalk, G. (1965) Biochem. Z., 341, 249-259.

12. Vogt, M. (1965) Arch. Mikrobiol., 50, 256-281.

13. Blackkolb, F. \& Schlegel, H. G. (1968) Arch. Mikrobiol., 63, 177-196.

14. Bowien, B., Cook, A. M. \& Schlegel, H. G. (1974) Arch. Microbiol., 97, 273-281.
15. Vishniac, W. \& Trudinger, Ph. A. (1962) Bacteriol. Rev., 26, 168-169.

16. Schneider, K. \& Schlegel, H. G. (1976) Biochim. Biophys. Acta, 452, 66-80.

17. Schink, B. (1977) Ph. D. Thesis, University of Göttingen.

18. Probst, I. (1975) Ph. D. Thesis, University of Göttingen.

19. Probst, I. \& Schlegel, H. G. (1976) Biochim. Biophys. Acta, 440, 412-428.

20. Pfitzner, J. (1972) Zentralbl. Bakteriol. Parasitenkd. Infektionskr. Hyg. Abt. 1, Orig. Reihe A, 220 , 396-401.

21. Yu, L. \& Wolin, M. J. (1972) J. Bacteriol., 109, 59-68.

22. Hyndman, L. A., Burris, R. H. \& Wilson, P. W. (1953) J. Bacteriol., 65, 522-531.

23. Gitlitz, P. H. \& Krasna, A. I. (1975) Biochemistry, 14, 2561-2567.

24. Adams, M. W. W. \& Hall, D. O. (1977) Biochem. Biophys. Res. Commun., 77, 730-737. 